\title{
Implementation of the Islamic Work Ethics "AKHLAK" at Bank Syariah Indonesia in Bandung
}

\author{
Nurfahmiyati ${ }^{1 *}$, Rini Lestari ${ }^{2}$, Magnaz Lestira Oktaroza ${ }^{3}$, Asyifa Nur Azizah ${ }^{4}$, Liliani Sumarni Pratiwi ${ }^{5}$, M. $^{\circ}$ \\ Rafi Farandhi Lathifiana ${ }^{6}$ \\ 1, 4, 5 Faculty of Economics and Business, Development Economics Program, Universitas Islam Bandung \\ ${ }^{2,3,6}$ Faculty of Economics and Business, Accounting Study Program, Universitas Islam Bandung \\ *nurfahmiyati.unisba@gmail.com
}

\begin{abstract}
This research is conducted because there are still many fraud cases in Islamic bankings. This fraud is related to the behavior of managers and the employees in Islamic banking institutions. Therefore this fraud should be eliminated by applying the Islamic Work Ethics or moral values that exist in Islamic teachings. Based on this, this research aims to determine the understanding and application of Islamic Work Ethics in Islamic banking institutions. The research is a preliminary survey in an sharia bank in Bandung using qualitative research method. This method is carried out through interviews with the employees and leaders at Bank Syariah Indonesia. The results of interviews with the employees are then triangulated with the results of interviews with the leaders. This research is not a generalization. The results show the understanding and application of Islamic Work Ethics by employees and leaders at Bank Syariah Indonesia in Bandung. This study provides an overview to the government regarding the application of Islamic Work Ethics in Islamic banks.
\end{abstract}

Keywords : Islamic Work Ethics, AKHLAK, Bank Syariah Indonesia.

DOI: $10.7176 / \mathrm{IKM} / 11-4-07$

Publication date: July $31^{\text {st }} 2021$

\section{INTRODUCTION}

The current development of Islamic banking performance has not met the expectation of various stakeholders. In fact, the financial performance of sharia banking has decreased in recent years. This is due to the increasing number of non-performing loan over the last three years. Based on the data from OJK ( Financial Services Authority) by August 2020 (OJK, 2020) the number of non-performing financing in 2018 was 6.6 trillion rupiahs, increased from 7.2 trillion rupiahs in 2019 to 7.7 trillion rupiahs in July 2020.

The decline in sharia banking performance as evidenced by the large number of non-performing financing is caused by the many cases of deviation/ fraud committed by managers and employees at sharia banking institutions such as cases of fictitious financing worth 1.1 trillion rupiahs by authorized officials at Bank Syariah Mandiri (Saiman, 2018, Bank Syariah Mandiri Allegedly Provides Fictitious Financing of 1.1 Trillion rupiahs, via http://cnnindonesia.com [6/1/19, 16.50 wib) . Here were allegations of corruption cases worth 566 billion rupiahs in BJB syariah( Falatehan, Indra, 2018, Legal Advisor for Defendants in Corruption Cases Worth Rp. 566 Billion at BJB Syariah, Learn about the Prosecutor's Indictment, via http://jabar.tribunnews.com [6/1 /19, 5 p.m ). In 2019, there was a case of embezzlement of customer funds as much as 35 billion rupiahs at Bank Syariah Mandiri (MAKI, 2019, the Corruption Case of Bank Syariah Mandiri Simalungun Street in Place, via http://fin.co.id [5/11]/19, $10.00 \mathrm{am})$.

Those cases become the evidence that the management of sharia banking has violated sharia principles which ultimately leads to corruption and harms Indonesia. One of the principles of sharia in financial institutions is reflected in the work ethic of its employees. The existence of a work ethic in an agency cannot always be implemented properly, meaning that there are still deviations from the work ethic.

According to Ali and Al-Kazemi (2012), the concept of Islamic work ethics is derived from the Qur'an and the teachings of Prophet Muhammad which is contained in the Al-An'am paragraph 132 ,saying: "They all have ranks according to what they did; and your lord is not unaware of what they do."

Forster, G., \& Fenwick J. (2015) suggested that the Islamic work ethic provides a set of guidelines on how to work and to do business.

Moreover, Kadir (2015) stated that the Islamic Work Ethic teaches that doing actions "for God" and working as a form of worship under the following work ethics:

1) Work with good intentions.

2) Don't procrastinate

3) Be focus and serious

4) Work neatly 
5) Tawadhu ( be humble ) and gratitude

6) Do not forget to worship Allah S.W.T

There are also rules for the main values set by the Ministry of BUMN (State Owned - Enterprises) called AKHLAK . AKHLAK as Islamic work ethics are ethical values or morals that should be applied in a company including BUMN of Indonesia. These values provide direction as to what is right and what is wrong; what to do and what should not do; which ones should be encouraged and prioritized and which ones should not. In addition , cultural values must also be an inexhaustible source of energy. Islamic work ethic must be able to provide motivation for the employees in carrying out their daily activities . In order to become a solid foundation for the formation of employee behavior, these values must be easily memorized and understood by all employees, from the top management level to the implementers at the lowest level. AKHLAK stands for Amanah, Competent, Harmonious, Loyal, Adaptive, and Collaborative.

There has been much research relating to the implementation of the Islamic Work Ethic. The results of that research has had different results. Based on the research by Nurfahmiyati, Roosallyn and Riani (2019), employees and leaders in Islamic banking institutions have understood and applied Islamic work ethics at the work environment.

Aldulaimi (2016) suggested that Islamic ethical values are important to improve the efficiency and quality of an organization. The implementation of IWE leads to a better performance, as well as increased selfconfidence and satisfaction levels, by placing the needs of the organization as being greater than the needs of the individual and therefore experiencing a feeling of peace and tranquility in the workplace.

El-Kot (2016) agreed that there is a strong and significant relationship between IWE and the individual (employee). Furthermore, by replicating the findings of Ali and Yousef, El-Kot corroborates their findings that there is a positive relationship between IWE and job satisfaction and organizational commitment.

Gilani (2015) found that empirically ethical management is the most important part of Islamic bank operations. Gilani highlights the involvement of ethical differences in the approach and operational procedures of Islamic banks and non-Islamic banks, and how these are perceived by many stakeholders.

Tsafe and Rahman (2014 ) explains that the spiritual values of Islam affect the performance of Board service of the Islamic micro financial institutions in Malaysia. This study emphasizes that there is a paradigm shift in management science from initially focusing on profit to increasing social and religious responsibility.

Tobin (2014) said that the application of Islamic ethics in banking institutions is very complicated and complex. The implementation of Islamic values in banking practice is almost impossible and becomes a heavy burden for Islamic banks even though Islamic principles in Islamic economics are very simple, clear, and indisputable, even more emphasized that Islamic principles are absolute morals.

Furthermore, from the preceding description, the problem that will be discussed in this research is 'What is the understanding and the application of Islamic Work Ethics in Bank Syariah Indonesia in Bandung?'

\section{METHODS}

This reseacrh uses research methods with a qualitative approach. The research also uses a research method with a qualitative approach because it requires a comprehensive approach and a clear and in-depth picture to determine the understanding and application of Islamic work ethics in Bank Syariah Indonesia. The researcher uses the case study method in this study, namely the case in Islamic Banks. There are several reasons for using case studies, including: first, case study strategies are directed at a series of contemporary events, where researchers do not have the opportunity to control the events that will occur so that research results are difficult to manipulate. Second, the questions relate to "how" and "why", which are in accordance with the formulation of the research problem in this research. Third, the research focus on contemporary phenomena in real-life contexts. The focus of this research is how to interpret and apply Islamic work ethics in Bank Syariah Indonesia . Fourth, the boundaries between the phenomena and context are not clearly visible. Fifth, there are propositions or directions and research focuses that were built at the beginning of the research process (Basuki, 2016).

The case study research method has the following research design components (Basuki, 2016). The first is a research question : How do managers and employees at Islamic banks interpret and apply Islamic work ethics in carrying out their duties at Bank Syariah Indonesia ?. Second, make a proposition, the proposition of this research is the managers and employees who can interpret the Islamic work ethic and apply it in their daily work in work environment at Bank Syariah Indonesia. For this research, the proposition is at the end of the research, which is usually an exploratory research ( Basuki, 2016 ). Third, define the Units of Analysis . The unit of analysis of this research is Islamic work ethics, analyzing how to interpret and apply Islamic work ethics consisting of: 1). Logic that relates data to propositions. Linking data to the proposition can be done in the right way , by "pattern matching" which links some information. 2). Determine a criteria for interpreting the findings. 
The criteria to interpret the findings with the logic that links data with proposition to match the existing patterns makes a comparison between several propositions, which can be interpreted.

The type of case study used of the research is an exploratory case study. Exploratory research ( to explain ) is one that seeks to explore /compile the phenomena studied in order to answer the problems that have been formulated. In this type of research, research can formulate propositions, but it is also possibly unable to formulate propositions. The results of this type of research can be in the form of final results, or even in the form of propositions that may need to be tested in a further research (Basuki, 2016).

\section{RESULT AND DISCUSSION}

Based on the interviews with the employees and management of Bank Syariah Indonesia in Bandung. The information obtained is about the existence of the AKHLAK concept as a guideline for Islamic work ethics in Islamic banks. The AKHLAK concept was formed by the Ministry of BUMN, which has been implemented since February 2020. AKHLAK stands for Amanah, Competent, Harmonious, Loyal, Adaptive, and Collaborative. The explanation of AKHLAK is as follows:

1) Amanah means holding tight to the trust given; fulfilling promises and commitments, be responsible for tasks, decisions and actions taken and adhering to moral and ethical values.

2) Competent means continuing to learn and develop capabilities; improving a self-competence to answer challenges that are always changing, helping others to learn and completing tasks with the best quality.

3) Harmonious means caring for and respecting differences; respect people regardless of their background, such as helping each other and building a comfortable work environment.

4) Loyal means being dedicated and prioritizing the interests of the Nation and the State; maintaining the good name of fellow employees, leaders, BUMN and the State, willing to sacrifice to achieve a bigger goal and obeying the leadership as long as it does not conflict with law and ethics.

5) Adaptive means to continue to innovate and be enthusiastic in moving or facing change; quick-adapting themselves to be better, continuously making improvements following technological developments and proactively taking actions.

6) Collaborative means to build synergistic cooperation; providing opportunities for various parties to contribute, willing to work with a team to generate added value and mobilizing the use of various resources for common goals .

\section{IMPLEMENTATION OF AKHLAK}

Ru's understanding of the Amanah dimension is to hold the trust given. In addition, Ru also conveyed the meaning of each dimension. $\mathrm{K}$ stands for Competent which means individuals must continue to learn and develop their abilities. H stands for Harmony, which means individuals must care for each other and respect differences. $\mathrm{L}$ is for Loyal, means that employees have to dedicate themselves to the state and nation. A is adaptive, meaning that individuals have to be willing to innovate and have a passion for facing changes, and $\mathrm{K}$ is Collaborative; building synergistic collaboration. According to $\mathrm{Ru}$, the manifestation of the application of Competent is the changes made by sharia individuals following the changes that always occur in the banking world. This shows the toughness of Islamic bank employees. In relation to the Harmonious, there should be a harmony amongs the employees. It is necessary to care for each other and respect differences; different cultural identity and different culture background. In order to be tough, this must be accompanied by managing selfemotion/attitude in addition to work performance that must be continuously improved. According to $\mathrm{Ru}$, the dimension of Loyal must prioritize the interests of the nation and state, even though employees tend to prioritize their family interests. This is something normative. Adaptive means being able to adapt, and blend in. In this dimension, employees must be responsive to the changes that occur. To deal with the changes, employees must have adequate capabilities. This adequate ability means having to be competent. In addition, one must also be enthusiastic in carrying out work with the changes that occur. This adaptive application is very necessary also when an employee is transferred to another branch. This individu must be able to work well in a new environment, where there are new co-workers and new jobs. If they are not able to adapt, they will face a problem and might cause them to be less productive.

According to $\mathrm{Si}$, AKHLAK is related to an Islamic work ethic applied by Bank Syariah Indonesia . In Si's s opinion AKHLAK is an application of the qualities taught by the Prophet, namely sidiq ( truthful), amanah( upholding trust). AKHLAK also have the goal of prioritizing our morality and then it is translated into each of the pillars earlier, to their respective values. While Ad suggested the dimensions of AKHLAK; that an individual must be trustworthy in carrying out their duties; Competence means increasing ability, harmoniously related to cooperation that must be carried out in harmony, supporting each other, not bringing each other down. Loyal is associated with a sense of love for the workplace so as to provide the best results. Meanwhile 
collaborative means being able to describe the vision and mission of Bank Syariah Indonesia together among the existing legacy with a target to be included in the top 10 in the world.

To obtain the validity of the results of this interview, triangulation was conducted, ie checked and rechecked the information submitted by the employees compared with the results of the interviews result from the leaders in Bank Syariah Indonesia of Bandung. Triangulation was performed by interviewing a leader at Bank Syariah Indonesia related to his understanding and application of AKHLAK.

The leader interpreted Amanah as an integrity, a person who is trustworthy and honest. This is realized by efforts to get bonafide customers, work hard and focus on getting customers and comply with the instructions from the management.

For the second dimension, Competence, the leader interpreted Competence as a unit which is impossible for an incompetent employee to get closing for the products sold. However, this must be accompanied by the role of leaders who understand the capabilities of their employees. The third dimension, Harmonious, was conveyed by this leader that in one team it is not possible to do only one person's work, but because team members work together so that it can bring success. In relation to the Loyal dimension, when there is an urgent need, employees are willing to work 6 to 7 days a week, even though they only work 5 days a week. The Adaptive dimension is defined as constantly innovating. Regarding to the products that are owned, they must be able to sell consumers demand. Dimension of Collaborative is a good collaboration because there are many divisions in the work environment, and therefore they must work together to achieve their targets or goals.

\section{CONCLUSION}

Based on the results of the interviews with three employees representing the three banks that joined BSI, as well as triangulation of a leader at Bank Syariah Indonesia, the results of the qualitative analysis can be concluded that:

1) The Islamic Work Ethics in Bank Syariah Indonesia, namely AKHLAK is the core values set by the government for all BUMN in Indonesia. It has only been implemented at Bank Syariah Indonesia since early February 2021.

2) Bank Syariah Indonesia is a merger of three Islamic banks. Each of these banks has its own core values before merging into bank Syariah Indonesia.

3) The employees of Bank Syariah Indonesia have understood and applied the concept of AKHLAK in carrying out their work in the hope that it will improve the performance of the company.

\section{REFERENCES}

Abbasi, Abdus Sattar., Rehman, Khasif Ur., and Bibi, Amna., "Islamic Work Ethics: How it Affects Business Performance", Actual Problems of Economics, 312, 2011.

Abbasi, Abdus Sattar., Mir, Ghulam Mustafa., and Hussain, Muzammil., "Islamic Work Ethics: How it Affects Organizational Learning, Innovation and Performance", Actual Problems of Economics, 138, 2012.

Al-Douri, Jamal Ahmed., Aldabbagh, Issam, Mohammad, May Mousa., and Qawasmeh, Rasha A.A., "The Impact of Islamic Work Ethics on Job Performance with Mediating Role of Intrinsic Motivation", Academy Strategic Management Journal, Volume 19, Issue 2, 2020.

Al-shaibah., Habtoor, Nasser., and Noor, Khaerunneezam Bin Mohd., "Islamic Work Ethics and Employees' Performance with Mediating Effect of Job Satisfaction in Yemen”, International Journal of Industrial Management (IJIM), Vol. 3, June, 2017.

Ali, A.J, \& Al-Kazemi, A. A., "Islamic Work Ethic in Kuawit”, Cross Cultural Management: An International Journal, 14 (2), 93-104, 2012.

Ali, Ahmed Raja Ahmed Haj., Noordin, Kamaruzaman., and Achour, Meguellati., "The Islamic Approach of Obligation in mutual relations between Employee and Employer", International Journal of Ethics and Systems, 2018.

Basuki. Metode Penelitian Akuntansi dan Maanjemen Berbasis Studi Kasus, Surabaya: Airlangga University Press, 2016.

Creswell, J.W., Qualitative Inquiry \& Research Design: Choosing Among Five Approach. Yogyakarta: Pustaka Pelajar, 2015.

Din, Maaz Ud., Khan, Faisal., Khan, Usman., and Kadarningsih, Ana., "Effect of Islamic Work Ethics on Job Performance: Mediating Role of Intrinsic Motivation, International Journal of Islamic Business Ethics, 4 (2), September, 2019.

Falatehan, Indra, 2018, Penasihat Hukum Terdakwa Kasus Korupsi Senilai Rp 566 Miliar di BJB Syariah, Pelajari Dakwaan Jaksa, melalui http://jabar.tribunnews.com [6/1/19, 17.00 wib]. 
Febriani, Rizki., Asfiah, Nurul., dan Nurhasanah, Siti., "Penerapan Nilai-Nilai Islami dan Relevansinya dengan Peningkatan Komitmen Kerja Karyawan”, Falah: Jurnal Ekonomi Syariah, 4 (1), 21-32, 2019.

Forster, G., \& Fenwick, J., "The Influence of Islamic Values on Management Practice in Morocco", European Management Journal, 33 (2), 143-156, 2015.

Ghada A. El-Kot and Ronald J. Burke , (2014),"The Islamic work ethic among employees in Egypt", International Journal of Islamic and Middle Eastern Finance and Management, Vol. 7 Iss 2 pp. 228 235

Hadisi, Mitra., "The Effect of Islamic Work Ethics on the Performance of Muslim Employee of Marketing Sector in Multinational Companies, International Journal of Organizational Leadership, 3, pp: 31-40, 2014.

Hasan Gilani , (2015),"Exploring the ethical aspects of Islamic banking", International Journal of Islamic and Middle Eastern Finance and Management, Vol. 8 Iss 1 pp. 85 - 98

Hayati, Keumala., Yuningsih., and Caniago, Indra., "Can Islamic Work Ethics and Ethical Climate Reduce Counterproductive Work Behavior?", International Journal of Economics, Business and Enterpreneurship (IJEBE), Vol.1, No.2, 2018.

Husin, Wan Norhasniah Wan., and Kernain, Nur Farahana Zul., "The Influence of Individual Behaviour and Organizational Commitment Towards the Enhancement of Islamic Work Ethics at Royal Malaysian Air Force”, Journal of Business Ethics, 1-11, 2019.

Imam, Awais., Abbasi, Abduss Sattar., and Muneer, Saima., "Employee Performance From The Lens of Islamic Work Ethics: Mediating Role of Personality X and Y”, Sci,Int, (Lahore), 27 (1), 415-422, 2015.

Jalal, Raja Nabeel-Ud-Din., Zaheer, Muhammad Asif., and Sultan, Faisal, "Ineractive Effect of Islamic Work Ethics on the Relationship of Supervisor Support, Compensation, Training \& Development with Organizational Commitment", International Journal of Economics, Commerce and Management, Vol. V, Isuue 9, September, 2017.

Kadir, Akob.,Muh, "Etika Kerja dalam Perspektif Islam”, Penerbit Yayasan Pencerahan Sulawesi, ISBN: 978979-3247-70-6, 2015.

Lestari, Rini., Sofianty, Diamonalisa., dan Kuntorini Ririn Sri., “The Influence of Quality of Management Accounting Information System on the Implementation of Good Corporate Governance and It Impacts on the Company Performance", Proceedings of the $1^{\text {st }}$ Social and Humaniora Research Symposium (SoRes 2018), Volume 307, 2019.

Lestari, Rini., Sofianty, Diamonalisa., dan Kuntorini Ririn Sri. "Factors Influence on the Quality of Management Accounting Information System and Its Impacts on Good Corporate Governance Implementation", Proceedings of the 2nd Social and Humaniora Research Symposium (SoRes 2019), Volume 409, 2020.

MAKI, 2019, Kasus Korupsi Bank Syariah Mandiri Simalungun Jalan di Tempat, melalui http://fin.co.id [5/11/19, $10.00 \mathrm{wib}]$.

Nasution, Fahmi Natigor., "Islamic Work Ethics, Organizational Commitment and Job Satisfaction of Islamic Banks in Indonesia”, RAUSP Management Journal, Vol 55, N0. 2, July, 2020.

Nurfahmiyati., Roosallyn., dan Riani "Islamic Work Ethics Implementation in Islamic Bank", Proceedings of the $1^{\text {st }}$ Social and Humaniora Research Symposium (SoRes 2018), Volume 307, 2019.

OJK, 2020, Statistik Perbankan Syariah, melalui https://www.ojk.go.id/ [2/12/2020, 10.25 wib].

Permana, Angrian., Aima, M. Havidz., Ariyanto, Eny., dan Nurmahdi, Adi., "The Effect of Leadership Style, Motivation and Discipline of Employee Performance with Understanding of Islamic Work Ethics", International Journal of Scientific \& Technology Research, Volume 8, Issue 08, August, 2019.

Rizki, Febriani., Armanu, Thoyib, Surachman, S., and Rofiaty, R., "Study on the Relationship between Islamic Leadership Style, Work Ethics, Job Satisfaction, and Employee Performance", Russian Journal of Agricultural and Socio-Economic Sciences, 61 (1), 2017.

Rokhman, Wahibur., "Islamic Work Ethics As An Antecedent of Work Outcome: A Study of Islamic Microfinance in Central Java, Indonesia”, Qudus International Journal of Islamic Studies, Vol.2, No.1 April, 2014.

Saeed Hameed Aldulaimi , (2016),"Fundamental Islamic perspective of work ethics", Journal of Islamic Accounting and Business Research, Vol. 7 Iss 1 pp. $59-76$

Saiman, B., 2018, Bank Syariah Mandiri Diduga Beri Pembiayaan Fiktif Rp 1,1 T, melalui http://cnnindonesia.com [6/1/19, 16.50 wib].

Salahudin, Shahrul Nizam., Baharuddin, Siti Sarah., Abdullah, Muhammad Safizal., and Osman, Abdullah., "The Effect of Islamic Work Ethics on Organizational Commitment", Procedia Economics and Finance 35, pp: 582-590, 2016.

Sarah A. Tobin . "Is it Really Islamic?" Evaluating the "Islam" in Islamic Banking in Amman, Jordan" In Production, Consumption, Business and the Economy: Structural Ideals and Moral Realities. Published online: 10 Oct 2014; 127-156. 
Shafique, Muhammad Nouman., Haseeb, Muhammad., Ahmad, Naveed., Kurshid, Mahboob., and Ahmad, Hussain., "The Influence of Islamic Work Ethics on Job Satisfaction and Organization Commitment", Journal of Marketing and Consumer Research, Vol.14, 2015.

Tsafe, Bashir Mande; Rahman, Rashidah Abd. 2014. Effects of Spirituality on Board Service Performance in Malaysian Microfinance firms Journal of Finance, Accounting and Management, 5(1), 88-108, Jan 2014.

Usman, Muhammad., Shahzad, Khurram., and Khan, Khurram "Islamic Work Ethics (IWE): A Review Literature and Direction for Future Research", Journal of Islamic Business and Management, Vol.5, No. 2, 2015.

Wahyudi, Amin., "The Influence of Organizational Commitment and Islamic Work Ethic Toward Job Performance of Teaching Staff at Universities in Surakarta with Institutional Base as Moderator Variable", Proceedings of the $35^{\text {th }}$ Anniversary Slamet Riyadi University, Unisri Solo, 2015.

Widiansyah, Fauzan Akbar., "Etika Kerja Islam Sebagai Faktor Determinan Terhadap Kinerja Karyawan PT.X di Kota Bandung”, Jurnal Riset Manajemen: IMAGE, Vol.8 No.2, 2019.

Yesil, Salih., Sekkeli, Zumrut Hatice., and Dogan, Ozkan., “An Investigation into Implications of Islamic Work Ethic (IWE) in the Workplace", Journal of Economics and Behavioral Studies, Vol.4, No.11, pp. 612624, Nov, 2012.

Zin, SM., Mat, RC., Manaf, KA., Muhammad, N., Mansor, FA., and Hashim, MZ., "Identifying ImportancePerformance Matrix Analysis (IPMA) of Intellectual Capital and Islamic Work Ethics in Malaysian SMES”, Journal of Fundamental and Applied Science 10 (1S), 793-805, 2018. 